\title{
Improving Community Performance by Re-examining Public Services ${ }^{1}$
}

\author{
Randall A. Cantrell ${ }^{2}$
}

\section{Quick Facts}

- Community-sponsored events have the most impact if they can bring citizens together who may not otherwise meet one another (Guetzkow, 2002).

- Only one-fourth of adults routinely achieve a recommended level of at least 30 minutes of physical activity each day (Ham, Kruger, \& Tudor-Locke, 2009).

\section{Terms to Help You Get Started}

Community: The neighborhoods, public schools, and public services found in a specific area

Overall community performance: How well neighborhoods, public schools, and public services address citizens' needs and desires

\section{Keywords}

Community performance, citizen behaviors, neighborhoods, public schools, public service

\section{Introduction}

This series of EDIS publications introduces readers to the concept of overall community performance and suggests minor modifications to neighborhoods, public schools, and public services that could help citizens improve their communities. This publication is for a general audience and provides a list of changes to public services that, if enacted, may help improve a community's performance. The other three publications in this series include the following:

- Improving Community Performance by Re-examining the Neighborhood (http://edis.ifas.ufl.edu/fy1372)

- Improving Community Performance by Re-examining Public Schools (http://edis.ifas.ufl.edu/fy1374)

- Improving Savings, Health, and Happiness by Making Small Modifications to Your Community (for an academic audience) (http://edis.ifas.ufl.edu/fy1371)

\section{Benefits of Community Gatherings}

A small town of 25,000 residents held a series of free outdoor concerts in the town square. Two families who did not know each other sat next to one another on blankets and lawn chairs. The children began dancing to the music, and the parents started talking. During the conversation, the wives of the families realized their husbands both had similar health issues that required similar treatment. One of the fathers recently started a walking regime as part of his rehabilitation while the other father had slipped back into less healthy habits. The wives agreed to stay in touch so the two fathers could begin walking together. They did so, and now the two fathers have progressed to the point of running

1. This document is FCS3316, one of a series of the Department of Family, Youth and Community Sciences, Florida Cooperative Extension Service, Institute of Food and Agricultural Sciences, University of Florida. First published May 2013. Please visit the EDIS website at http://edis.ifas.ufl.edu.

2. Randall A. Cantrell, assistant professor, Department of Family, Youth and Community Sciences; Florida Cooperative Extension Service, Institute of Food and Agricultural Sciences, University of Florida, Gainesville, FL 32611.

This material was prepared with the support of the University of Florida. However, any opinions, findings, conclusions, or recommendations expressed are those of the author(s) and do not necessarily reflect the views of the University of Florida. 
with one another. The families also gather routinely to enjoy each other's company. This story is one example of how good public services can benefit the community, bring people closer together, and possibly improve overall community performance.

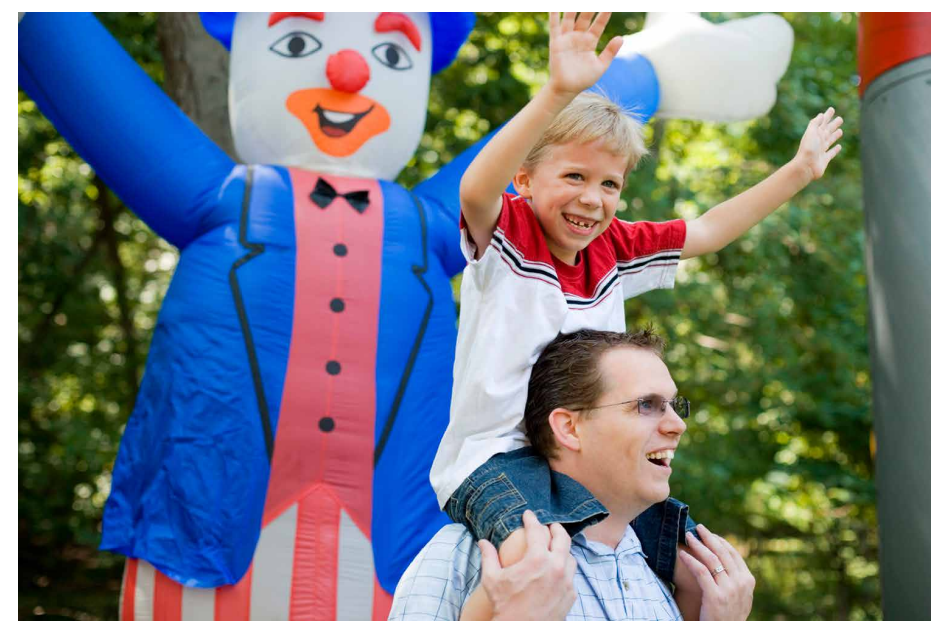

Figure 1. Community gatherings, such as holiday concerts or festivals, give families a chance to come together with their neighbors and may help to build relationships in the community.

Credits: Creatas

\section{How Might Your Family Benefit by Improving Overall Community Performance?}

The concept of overall community performance has much to do with re-thinking how people can be happier, which is not the same as being comfortable. Finding ways for citizens of the same community to peacefully share space and time is not an easy task. Making friends in the community rather than having casual acquaintances is an attainable goal and one worthy of pursuit. When families focus on the various factors comprising overall community performance, they may be able to save time and money and also strengthen the neighborhood and community. However, improving the community sometimes takes place in small increments and requires time before results are noticeable.

\section{How Are Public Service}

\section{Considerations Chosen to Improve} Overall Community Performance?

Respondents from a representative sample in the United States were asked to rate multiple items-as identified in the literature-that could improve the overall performance of a community (Cantrell \& Stafford, 2013). The goal was to determine which of 81 items the respondents thought had the greatest likelihood of improving their community's overall performance. In the public service considerations category, respondents chose 20 of 27 modifications.

\section{Public Service Considerations That Most Impact Community Improvement}

List 1 shows the public service considerations sample participants felt could have the most impact on improving overall community performance. These considerations mostly include citizen interaction programs.

\section{List 1. Public Service Considerations That Most Impact Overall Community Improvement}

- More locally sponsored events

- More arts and performances

- A community information website updated daily

- A well-maintained and patrolled community center

- More youth sports programs

- Having a youth acting (performing arts) program

- Having (or increasing) community-led exercise and nutrition programs

\section{Public Service Considerations That Marginally Impact Community Improvement}

List 2 shows the public service considerations sample participants felt could marginally improve overall community performance. These considerations mostly include community-sponsored events.

\section{List 2. Public Service Considerations That Marginally Improve Overall Community Performance}

- Better landscaped public grounds

- A better maintained and patrolled library

- More community guest speakers

- More adult sports programs

- More town hall meetings

- Having a town historical center

- Having programs that reward citizens for volunteering 
- Providing more information on energy conservation topics

- Providing more convenient access to information about University Extension programs

- Providing access to reclaimed water for use in irrigating lawns

- Providing bike lanes on public access routes

- Better recycling services

- Providing a website to make online payments for all services/utilities

\section{Summary}

Making minor modifications to public services will not necessarily result in instant improvements to overall community performance. However, if changes to public services are made along with other community-performance measures (e.g., modifications to neighborhoods and public schools), the results will become noticeable over time. The point is not to seek instant results but rather to establish practices that provide citizens with as many of their needs and desires as possible.

\section{References}

Cantrell, R. \& Stafford, A. (2013). The introduction and development of the community-flow measurement instrument. Journal of Community Development. doi:10.1080/155 75330.2012 .761640

Guetzkow, J. (2002). How the arts impact communities: An introduction to the literature on the arts impact studies. Princeton Center for the Arts and Cultural Policy Studies, 1-26. Retrieved from http://www.princeton.edu/culturalpolicy/workpap/WP20\%20-\%20Guetzkow.pdf

Ham, S. A., Kruger, J. \& Tudor-Locke, C. (2009). Participation by U.S. adults in sports, exercise, and recreational physical activity. Journal of Physical Activity and Health 6(1), 6-14. 